African Crop Science Journal by African Crop Science Society is licensed under a Creative Commons Attribution 3.0 Uganda License. Based on a work at www.ajol.info/ and www.bioline.org.br/cs DOI: https://dx.doi.org/10.4314/acsj.v27i3.11

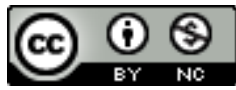

\title{
IN VITRO ANALYSIS OF ANTIMICROBIAL AND PHYTOCHEMICAL PROPERTIES OF CRUDE EXTRACTS OF SELECTED PLANTS AGAINST THE TOMATO WILT DISEASE
}

\author{
B.N. ALOO, P. OLUKO ${ }^{1}$ and B. WANJOHI ${ }^{2}$ \\ University of Eldoret, School of Science, P. O. Box 1125-30100, Eldoret, Kenya \\ ${ }^{1}$ University of Eldoret, School of Agriculture and Biotechnology, P. O. Box 1125-30100, \\ Eldoret, Kenya \\ ${ }^{2}$ University of Eldoret, School of Natural Resource Management, University of Eldoret, \\ P. O. Box 1125-30100, Eldoret, Kenya \\ Corresponding author: aloobecky@yahoo.com
}

(Received 14 March 2018; accepted 13 August 2019)

\begin{abstract}
The wilt disease by fungal and bacterial pathogens is one of the most devastating diseases of tomato (Solanum lycopersicum L.) worldwide. Chemical-based control of the wilt-causing pathogens often leads to environmental pollution and pest resistance; hence the need for alternative sustainable approaches. We evaluated the in vitro antimicrobial and phytochemical properties of aqueous crude extracts of roots, leaves, flowers, and barks of Solanum incanum L., Laurnea cornuta, Tagetes minuta L., Ageratum conyzoides, Opuntia monacantha, and Euphorbia tirucalli L. from Kano-Kisumu against Erwinia chrysanthema, Ralstonia solanacearum and Fusarium oxysporum isolated from diseased tomato tissues and rhizospheres. Sterile distilled water and the amoxicillin antibiotic were used as negative and positive control treatments, respectively. The experiment was carried out in diameters of zones of inhibition and levels of phytochemicals determined. Ageratum conyzoides and O. monacantha extracts were least effective against the pathogens, with means of inhibition of only up to 8.7 and 12.3 $\mathrm{mm}$, respectively. Euphorbia tirucalli and L. cornuta were the most effective against the pathogens, with means of inhibition of up to $30 \mathrm{~mm}$. Except for anthocyanins and anthraquinones, no significant $(\mathrm{P}<0.05)$ differences were observed for levels of other phytochemicals in different plant extracts. We concluded that plant extracts showing remarkable antimicrobial activities against the pathogens can be used to make viable formulations to combat the devastating tomato wilt disease.
\end{abstract}

Key Words: Bacterial wilt, plant extracts, Solanum lycopersicum

\section{RÉSUMÉ}

La maladie flétrissures causée par des agents pathogènes fongiques et bactériens est l'une des maladies les plus dévastatrices de la tomate (Solanum lycopersicum L.) dans le monde. La lutte chimique contre les agents pathogènes responsables du flétrissures entraîne souvent une pollution 
de l'environnement et une résistance aux ravageurs; d'où la nécessité d'approches alternatives durables. Nous avons évalué in vitro les propriétés antimicrobiennes et phytochimiques d'extraits bruts aqueux de racines, feuilles, fleurs et écorces de Solanum incanum L., Laurnea cornuta, Tagetes minuta L., Ageratum conyzoides, Opuntia monacantha et Euphorbia tirucalli L. de Kano- Kisumu contre Erwinia chrysanthema, Ralstonia solanacearum et Fusarium oxysporum isolés de tissus et de rhizosphères de tomate malades. L'eau distillée stérile et l'antibiotique amoxicilline ont été utilisés comme traitements témoins négatifs et positifs, respectivement. L'expérience a été réalisée dans des diamètres de zones d'inhibition et des taux de composés phytochimiques déterminés. Les extraits d'Ageratum conyzoides et d' $O$ monacantha étaient les moins efficaces contre les agents pathogènes, avec des moyens d'inhibition de seulement 8,7 et 12,3 mm, respectivement. Euphorbia tirucalli et L. cornuta se sont révélés les plus efficaces contre les agents pathogènes, avec une inhibition pouvant atteindre $30 \mathrm{~mm}$. À l'exception des anthocyanes et des anthraquinones, aucune différence significative $(\mathrm{P}<0,05)$ n'a été observée pour les concentrations d'autres composés phytochimiques dans différents extraits de plantes. Nous avons conclu que des extraits de plantes présentant des activités antimicrobiennes remarquables contre les agents pathogènes peuvent être utilisés pour élaborer des formulations viables permettant de lutter contre la maladie dévastatrice de la tomate.

Mots Clés: Flétrissure bactérienne, extraits de plantes, Solanum lycopersicum

\section{INTRODUCTION}

Tomato (Solanum lycopersicum L.) is the second most important vegetable crop in the world, cultivated widely in the tropics and subtropics (AVRDC, 2015; McGovernn, 2015). It provides smallholder farmers in East Africa with higher incomes per hectare than other staple crops (AVRDC, 2015). Due to its nutritive and economic importance, the tomato has become the agenda in international horticultural fora (Ayandiji and Adeniyi, 2017).

Despite its economic and nutritional importance, tomato production is affected by many diseases in sub-Saharan Africa (James et al., 2010; Sang et al., 2016). It is reported that $F$. oxysporum and other tomato pathogens are responsible for huge losses in tomato production globally (Hanaa et al., 2011). The bacterium, $R$. solanacearum, is classified as one of the world's important phytopathogens due to its persistence, lethality, wide host range and broad geographic distribution (Deny, 2006; Janse, 2012); and is reported to contribute to tomato yield losses of between 10-100\% worldwide (Radhi et al., 2016).

Control of tomato pests and pathogens, just like in other crops, is largely dependent on chemical pesticides (Akkopru and Demir, 2005;
Birech et al., 2006; Yuliar et al., 2015). However, this is undesirable because of development of pathogen resistance (Wagnitz, 2014), the high costs involved and the persistence and accumulation of these chemicals in the environment, as well as their effects on non-target organisms (Rai and Carpinella, 2006; Engindeniz and Ozturk, 2013; Bhattacharjee and Dey, 2014). There is need, therefore, to search for alternative ways to control and manage tomato pests and diseases.

Natural plant products seem to be a viable and appealing solution to the aforementioned problems, and many researchers worldwide are seeking to identify the effective natural products that can replace the synthetic pesticides (Kim et al., 2005). It is widely known that many plants are good sources of antimicrobial agents (Obafemi et al., 2006), and several plants have been shown to contain bioactive constituents (Awoyinka et al., 2007). There is evidence that plants produce a variety of bioactive metabolites and phytochemicals, which serve as their defense mechanisms against pests (Tenover, 2006). Authors have previously observed that the potential of plants as sources of useful compounds, remains largely unexplored and screening of plants 
may result in the discovery of novel compounds that could be valuable, especially in the wake of pathogen resistance (Tomoko et al., 2002). In this context, there is need for exploration of plant extracts as alternative pathogen control agents to combat microbial infections.

Pesticides from natural sources are often non-toxic to humans and the environment, easily degradable and do not accumulate in the environments as in the case of synthetic pesticides (Wagnitz, 2014). The use of natural products as biological control mechanisms are considered a viable alternative to synthetic products because of their efficiency (Chethana et al., 2012; Nashwa and Abo-Elyousr, 2012). In this study, we sought to assess the antimicrobial and phytochemical properties of crude extracts of various plant parts (the roots, barks, leaves, and flowers of $L$. cornuta, A. conyzoides, E. tirucalli L, T. minuta L, $S$. incanum L. and $O$. monacantha) of selected plants against the common tomato wilt-causing pathogens; E. chrysanthema, $R$. solanacearum and $F$. oxysporum. The objective was to evaluate the antimicrobial activities of the crude extracts of different parts of various herbs against selected tomato plant pathogens in vitro and thus, to identify plants or parts of plants whose extracts have the potential to be used in managing the tomato wilt disease.

\section{MATERIALS AND METHODS}

Study and sampling areas. The study was conducted at the University of Eldoret, Biotechnology laboratory and in the greenhouse located nearby. Two sampling locations; Alendu Mixed Secondary School (E 0.156693 N 34: 811165) and Migingo Primary School (E $0.156589 \mathrm{~N} 34.811310$ ) were selected for this study.

Plant sampling, identification and handling. The sampling of plant specimens for this study was done in December, 2016 in Kano Kisumu. The fresh leaves, flowers, barks and roots of six plants (L. cornuta, A. conyzoides, $T$. minuta
$\mathrm{L}, S$. incanum L., and $O$. monacantha) were sampled and transported in labeled clean polyethylene bags to the Biotechnology laboratory at the University of Eldoret for further analysis. For E. tirucalli L., only the roots, bark and the thorny needle-like leaves were sampled since the flowers were not present at the time of sampling. In total, 23 plant specimens were collected for the study. The six plant samples were identified by a taxonomist from the School of Natural Resources, University of Eldoret as $L$. cornuta, A. conyzoides, E. tirucalli L, T. minuta $\mathrm{L}, S$. incanum L., and $O$. monacantha (Table 1). The specimens were deposited in the University of Eldoret herbarium with the voucher numbers KSMBW/11/16/001, KSMBW/11/16/002, KSMBW/11/16/003, KSMBW/11/16/004, KSMBW/11/16/005 and KSMBW/11/16/006, respectively. Images of the different plant species which were sampled for this study are illustrated in Figure 1.

Preparation of plant extracts. Crude plant extracts were obtained following procedures previously described by Nduagu et al. (2008). The collected leaves, flowers, barks, and roots were cleaned with running tap water, rinsed with sterile distilled water and air-dried in the greenhouse for two weeks before being ground into fine powders using an automatic grinding machine (SM-1303FL). From each plant part, three different concentrations were formulated by weighing and suspending 1,5 and $15 \mathrm{~g}$ each into $100 \mathrm{ml}$ of sterile distilled water to obtain concentrations of $0.01,0.05$ and 0.15 $\mathrm{g} \mathrm{l}^{-1}$, respectively. The three different concentrations were denoted as low, medium and high, respectively; throughout the study. The suspensions were left overnight in a shaking water bath at $40{ }^{\circ} \mathrm{C}$; and subsequently, the mixtures were filtered using sterile pieces of muslin cloth. The filtrates were stored at 4 ${ }^{\circ} \mathrm{C}$ to preserve them for subsequent experiments.

Pathogen isolation. The test pathogens, $E$. chrysanthema, Ralstonia solanacearum, and 
TABLE 1. Plants used for antimicrobial and phytochemical assays

\begin{tabular}{lll}
\hline Botanical name & Common name & Family \\
\hline Laurnea cornuta & Bitter Lettuce & Asteraceae/Compositae \\
Ageratum conyzoides & Goat weed & Asteraceae/Compositae \\
Euphorbia tirucalli $L$ & Firestick plant/Pencil cactus & Eurphorbiaceae \\
Tagetes minuta L & Mexican Marigold & Asteraceae/Compositae \\
Solanum incanum L & Sodom Apple & Solanaceae \\
Opuntia monacantha & Prickly Pear & Cactaceae \\
\hline
\end{tabular}

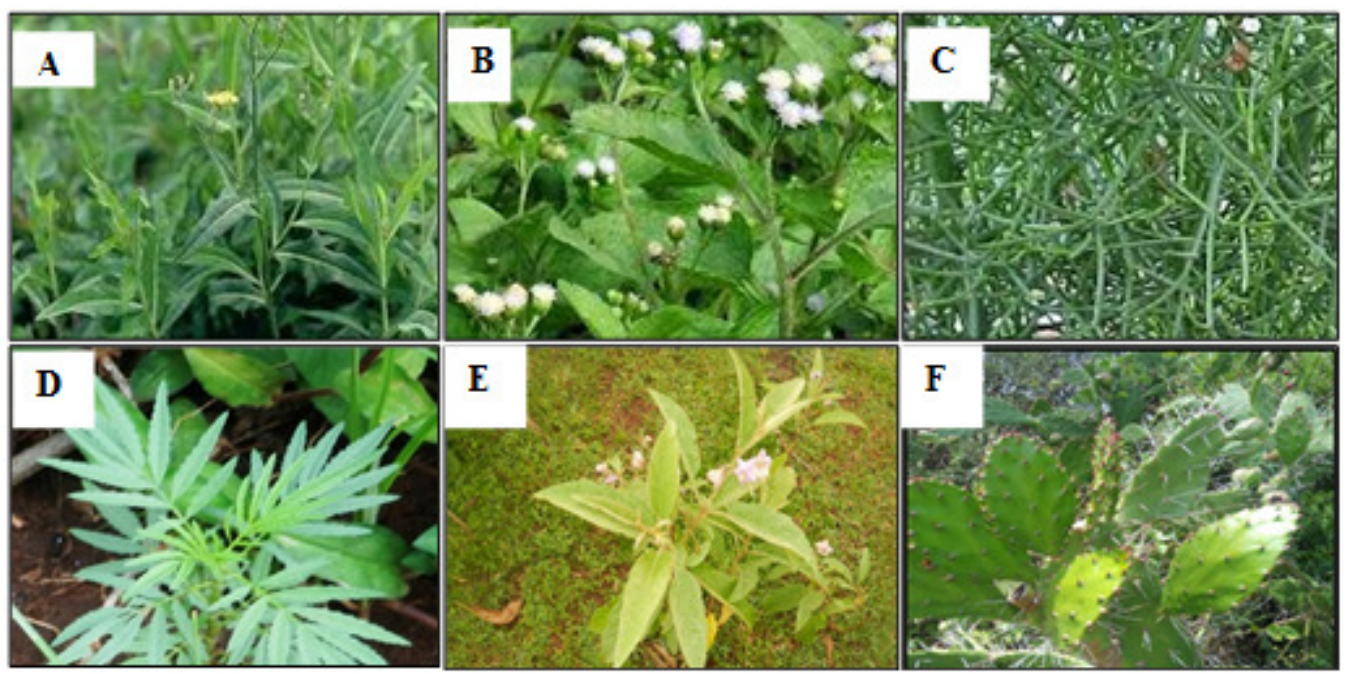

Figure 1. Images of the six plants used in the study A: Laurnea cornuta, B: Ageratum conyzoides, C: Euphorbia tirucalli L, D: Tagetes minuta L, E: Solanum incanum L. and F: Opuntia monacantha.

F. oxysporum and Ralstonia solanacearum, were isolated and identified from freshly sampled soil and root tissues from infected tomato plants following standard procedures as previously described by Lin et al. (2008); Janse (2012), and Sravani et al. (2014). Isolation of $F$. oxysporum, $R$. solanacearum and E. chrysanthema was done on Potato Dextrose Agar (PDA), Kelman's' Tetrazolium Chloride (TZC) agar and Crystal Violet Sodium Polypectate (CVP) agar, respectively. The $F$. oxysporum isolates were maintained on PDA slants at room temperature; while $E$. chrysanthema and $R$. solanacearum isolates were maintained on Nutrient agar slants at $37^{\circ} \mathrm{C}$. Identification of $F$. oxysporum was done after incubation at $25^{\circ} \mathrm{C}$ for 7 days, using the single spore method (Choi et al., 1999), and according to morphological characteristics with the help of standard keys of identification (Agrios, 2005).

Antimicrobial assays. The Agar Well Diffusion method (Joshi et al., 2009; Bhalodia and Shukla, 2011), was used to perform the antimicrobial assays for the bacterial and fungal test pathogens on Nutrient Agar and Potato Dextrose agar respectively. The plates were inoculated with about $40 \mathrm{ml}$ of broth cultures of the bacteria and fungi using the spread plate technique. Three wells/holes of about $9 \mathrm{~mm}$ diameter each, were drilled in each of the 
prepared agar plates using sterile micropipette tips and equal volumes $(1 \mu \mathrm{l})$ of the different concentrations of previously prepared plant extracts introduced into the plates, with 3 plates acting as positive controls per plant part and 1 plate of three wells acting as a negative control per plant part.

Instead of the plant extracts, three different concentrations (low, high and medium) of amoxicillin antibiotic were introduced into the wells of the three positive control plates, and sterile distilled water was introduced into the wells of each of the negative control plates. The plates were incubated in an upright position, at $37^{\circ} \mathrm{C}$ for $24 \mathrm{hr}$. The diameters of zones of inhibition per plate were measured, following the period of incubation.

Phytochemical analyses. The qualitative and quantitative analyses of different phytochemicals in the different plant extracts, was performed using High-Performance Liquid Chromatography (HPLC) technique (Handa $e t$ al., 2008). The compounds tested for were steroids (STE), anthraquinone (ANT), alkaloids (ALKA), terpenoids (TER), saponins (SAPO), anthocyanin (ANTHO), flavonoids (FLAV), phenols-tannins (PHENO) and Ninhydrins (NINH).

Data analysis. The data were analysed using SAS version 9.1; whereby ANOVA (one way) was carried out to show statistical difference using the varying zones of inhibition between the test microbes exposed to the different extracts from $L$. cornuta, A. conyzoides, $E$. tirucalli L., T. minuta L, S. incanum L., and O. monacantha at $95 \%$ level of confidence. The test results were further subjected to a Tukey's post hoc test to separate the significantly different means.

\section{RESULTS}

Results on the antimicrobial activities of the crude aqueous extracts of the different plants against $F$. oxysporum, revealed that the activities of-of different extracts against this pathogen were significantly different $(\mathrm{P}<$ 0.05 ) at different concentrations (Table 2). No significant difference was observed for activities of $O$. monacantha bark extracts and $S$. incanum leaf and bark extracts against $F$. oxysporum across the different concentrations. Also, the root extracts of E. tirucalli and $L$. cornuta proved to be more potent on $F$. oxysporum than all the other root extracts, showing means of zones of inhibition of up to 13.7 and $15.7 \mathrm{~mm}$, respectively. The same trend was also observed for the bark and leaf extracts of these two plants against $F$. oxysporum, with means of zones of inhibition going up to 17.3 and $20.0 \mathrm{~mm}$ for L. cornuta leaf and bark extracts, respectively. Extracts of $A$. conyzoides and $O$. monacantha were the least effective, with means of zones of inhibition ranging only between 3.7 and $11 \mathrm{~mm}$ (Table 2); while the most effective extracts were E. tirucalli and $L$. cornuta. The crude flower extracts of $O$. monacantha, $S$. incanum, and $L$. cornuta showed the greatest antimicrobial activity against $F$. oxysporum (Table 2).

Results of the effects of different concentrations of different plant extracts on $R$. solanacearum are presented in Table 3. Results revealed that E. tirucalli, T. minuta, $S$. incanum, and L. cornuta extracts exhibited the greatest activity against $S$. solanacearum in the descending order with the ranges of 10.3 - 34.3, 9.3 - 19.3, $9.3-16.0$ and $8.7-16.0$ $\mathrm{mm}$, respectively. As a matter of fact, the leaf extracts of E. tirucalli were the most potent for $R$. solanacearum; while the crude extracts of $A$. conyzoides and $O$. monacantha were the least potent; exhibiting only means of inhibition of lows of 3.7 and $3.3 \mathrm{~mm}$, respectively; and highs of $11.0 \mathrm{~mm}$ for both plant extracts (Table $3)$. Except for the leaf, flower and root extracts of $S$. incanum and the leaf and root extracts of $L$. cornuta, significant differences were observed for the activities of different plant part extracts against $R$. solanacearum, which increased significantly with increased concentrations of the extracts. 
TABLE 2. Means of zones of inhibition (mm) of different concentrations of different plant extracts on Fusarium oxysporum

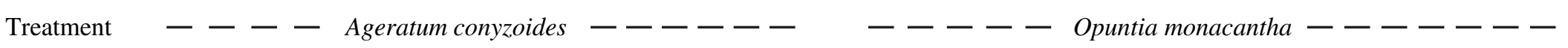

\begin{tabular}{lllllllll}
\hline & Root & Bark & Leaf & Flower & Root & Bark & Leaf & Flower \\
\hline -VE control & $0.0 \pm 0.0 \mathrm{a}$ & $0.0 \pm 0.0 \mathrm{a}$ & $0.0 \pm 0.0 \mathrm{a}$ & $0.0 \pm 0.0 \mathrm{a}$ & $0.0 \pm 0.0 \mathrm{a}$ & $0.0 \pm 0.0 \mathrm{a}$ & $0.0 \pm 0.0 \mathrm{a}$ \\
+ VE control & $6.0 \pm 0.7 \mathrm{~b}$ & $19.4 \pm 2.5 \mathrm{~d}$ & $6.0 \pm 0.7 \mathrm{~b}$ & $5.6 \pm 1.1 \mathrm{bc}$ & $5.9 \pm 0.8 \mathrm{~b}$ & $5.9 \pm 0.9 \mathrm{~b}$ & $5.3 \pm 0.8 \mathrm{~b}$ & $6.0 \pm 0.0 \mathrm{a}$ \\
Low conc. & $6.7 \pm 0.6 \mathrm{~b}$ & $3.7 \pm 0.1 \mathrm{~b}$ & $4.3 \pm 0.6 \mathrm{~b}$ & $5.0 \pm 0.6 \mathrm{bc}$ & $5.3 \pm 0.6 \mathrm{~b}$ & $6.0 \pm 0.6 \mathrm{~b}$ & $6.0 \pm 0.6 \mathrm{bc}$ & $8.0 \pm 1.0 \mathrm{c}$ \\
Med. conc. & $7.3 \pm 0.6 \mathrm{bc}$ & $4.7 \pm 0.6 \mathrm{c}$ & $6.0 \pm 1.0 \mathrm{~b}$ & $6.3 \pm 1.0 \mathrm{~b}$ & $6.3 \pm 0.6 \mathrm{bc}$ & $6.7 \pm 1.0 \mathrm{~b}$ & $6.7 \pm 1.1 \mathrm{~b}$ & $9.3 \pm 0.8 \mathrm{~d}$ \\
High conc. & $11.7 \pm 4.7 \mathrm{c}$ & $5.7 \pm 1.2 \mathrm{c}$ & $6.7 \pm 0.6 \mathrm{c}$ & $6.3 \pm 0.6 \mathrm{c}$ & $6.7 \pm 0.5 \mathrm{~b}$ & $6.7 \pm 1.2 \mathrm{~b}$ & $7.0 \pm 0.0 \mathrm{c}$ & $11.0 \pm 2.5 \mathrm{bc}$
\end{tabular}

---1 Tagetes minuta ------

\begin{tabular}{|c|c|c|c|c|c|c|c|c|}
\hline -VE control & $0.0 \pm 0.0 \mathrm{a}$ & $0.0 \pm 0.0 \mathrm{a}$ & $0.0 \pm 0.0 \mathrm{a}$ & $0.0 \pm 0.0 \mathrm{a}$ & $0.0 \pm 0.0 \mathrm{a}$ & $0.0 \pm 0.0 \mathrm{a}$ & $0.0 \pm 0.0 \mathrm{a}$ & $0.0 \pm 0.0 \mathrm{a}$ \\
\hline +VE control & $8.3 \pm 0.9 b$ & $7.4 \pm 0.8 b$ & $9.0 \pm 0.7 \mathrm{c}$ & $7.3 \pm 0.7 b$ & $8.1 \pm 0.9 b$ & $7.2 \pm 0.9 \mathrm{~b}$ & $8.7 \pm 0.5 \mathrm{c}$ & $7.2 \pm 0.9 b$ \\
\hline Low conc. & $7.7 \pm 0.6 b$ & $8.3 \pm 0.6 b c$ & $7.7 \pm 0.6 b c$ & $7.0 \pm 0.6 \mathrm{c}$ & $8.3 \pm 0.6 b$ & $8.3 \pm 0.6 c$ & $7.0 \pm 1.0 \mathrm{~b}$ & $8.3 \pm 0.6 b$ \\
\hline Med. conc. & $8.0 \pm 1.0 \mathrm{~b}$ & $8.3 \pm 3.4 b c$ & $8.3 \pm 1.2 b$ & $7.7 \pm 0.0 \mathrm{~b}$ & $8.7 \pm 0.6 c$ & $8.7 \pm 1.2 \mathrm{c}$ & $7.3 \pm 0.6 b$ & $9.0 \pm 1.0 \mathrm{~b}$ \\
\hline \multirow[t]{2}{*}{ High conc. } & $8.7 \pm 1.5 \mathrm{c}$ & $11.0 \pm 0.6 \mathrm{c}$ & $8.7 \pm 0.6 b$ & $8.7 \pm 1.2 b$ & $9.3 \pm 0.7 b c$ & $8.7 \pm 0.6 c$ & $7.0 \pm 0.0 \mathrm{~b}$ & $16.7 \pm 5.8 \mathrm{c}$ \\
\hline & --- & Euphorbia tirucalli & --- & & -- & - Laurnea & nuta & -- \\
\hline -VE control & $0.0 \pm 0.0 \mathrm{a}$ & $0.0 \pm 0.0 \mathrm{a}$ & $0.0 \pm 0.0 \mathrm{a}$ & & $0.0 \pm 0.0 \mathrm{a}$ & $0.0 \pm 0.0 \mathrm{a}$ & $0.0 \pm 0.0 \mathrm{a}$ & $0.0 \pm 0.0 \mathrm{a}$ \\
\hline +VE control & $8.0 \pm 0.0 \mathrm{~b}$ & $8.0 \pm 0.0 \mathrm{~b}$ & $8.0 \pm 0.0 \mathrm{~b}$ & & $8.0 \pm 0.0 \mathrm{~b}$ & $8.3 \pm 0.5 b$ & $8.7 \pm 0.5 b$ & $8.0 \pm 0.0 \mathrm{~b}$ \\
\hline Low conc. & $8.3 \pm 0.6 b$ & $9.0 \pm 1.0 \mathrm{bc}$ & $8.0 \pm 0.0 \mathrm{~b}$ & & $17.0 \pm 1.2 \mathrm{~b}$ & $14.3 \pm 2.5 \mathrm{c}$ & $12.0 \pm 0.0 \mathrm{c}$ & $10.7 \pm 0.7 \mathrm{c}$ \\
\hline Med. conc. & $9.7 \pm 0.8 \mathrm{c}$ & $7.7 \pm 1.2 \mathrm{~b}$ & $10.3 \pm 2.5 \mathrm{c}$ & & $10.0 \pm 2.0 \mathrm{c}$ & $16.3 \pm 3.7 \mathrm{~cd}$ & $11.0 \pm 2.0 \mathrm{~d}$ & $11.0 \pm 1.0 \mathrm{c}$ \\
\hline High conc. & $13.7 \pm 1.5 \mathrm{~d}$ & $12.0 \pm 3.6 \mathrm{c}$ & $12.7 \pm 2.5 \mathrm{c}$ & & $15.7 \pm 4.0 \mathrm{~cd}$ & $20.0 \pm 0.0 \mathrm{~d}$ & $17.3 \pm 0.6 \mathrm{e}$ & $16.3 \pm 3.2 \mathrm{~d}$ \\
\hline
\end{tabular}

Means followed by the same letter(s) within each column do not differ significantly at $\mathrm{P}>0.05$ (HSD) 
TABLE 3. Means of zones of inhibition ( $\mathrm{mm}$ ) of different concentrations of different plant extracts on Ralstonia solanacearum

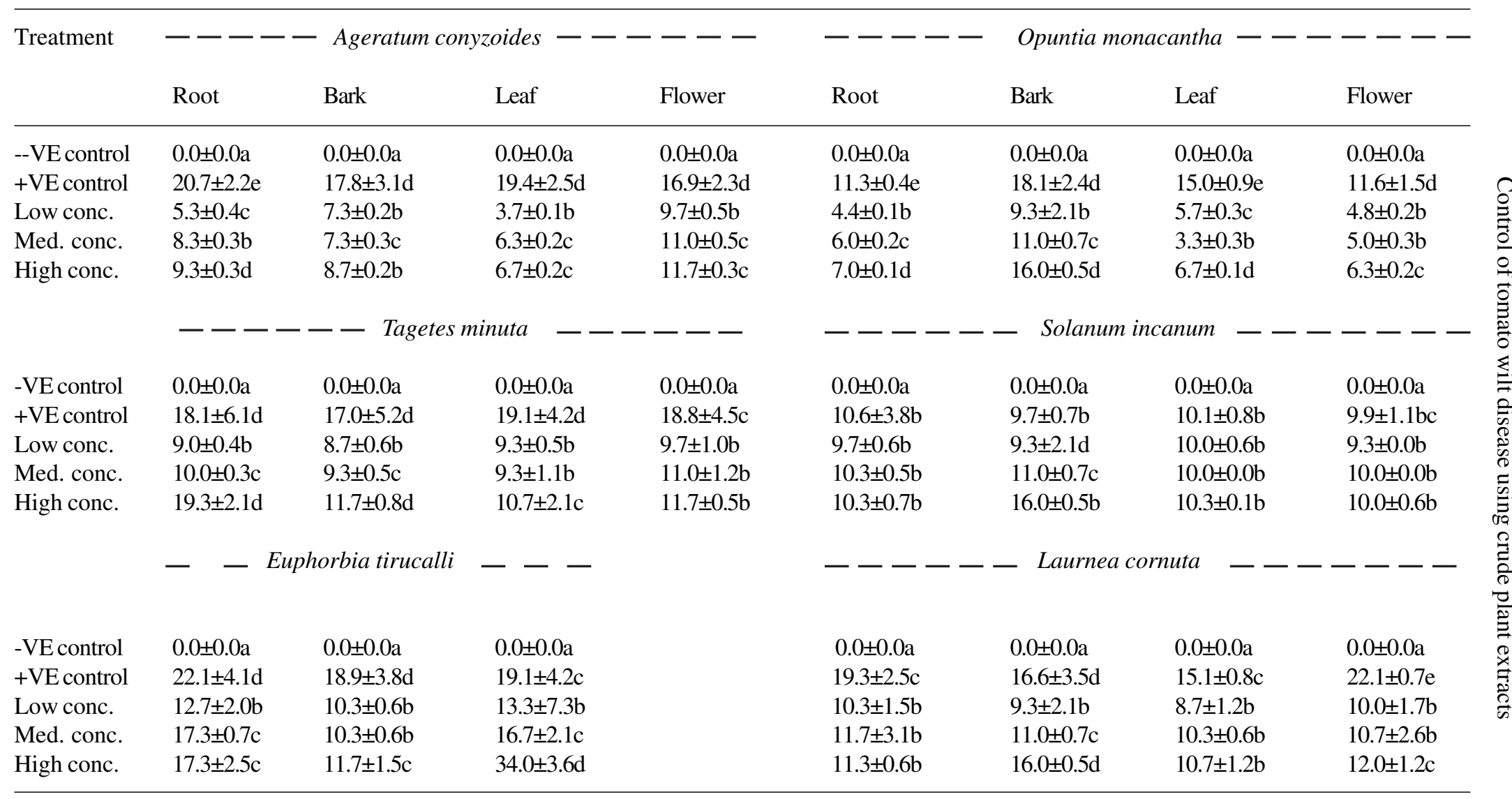

Means followed by the same letter(s) within each column do not differ significantly at P>0.05 (HSD) 
Results on the antimicrobial activities of the different plant extracts against $E$. chrysanthema are presented in Table 4. The activity of the different concentrations of extracts was significantly different $(\mathrm{P}<0.05)$. However, for the same plant, no significant $(\mathrm{P}$ $=0.216$ ) differences appeared in antimicrobial activity against this test pathogen among the different plant parts. Crude plant extracts from E. tirucalli and $L$. cornuta proved to be most effective against $E$. chrysanthema, than those from other plants under study.

It was to observed that for $S$. incanum and E. tirucalli, crude stem extracts gave significantly higher zones of inhibition than the other plant parts; while for $O$. monacantha and $A$. conyzoides, crude flower extracts gave higher zones of inhibition of E. chrysanthema than crude extracts from the other plant parts (Table 4). The least effective of all the plants extracts against $E$. chrysanthema were $A$. conyzoides and $O$. monacantha, which recorded means of inhibition ranging only between 6.0 to $8.7 \mathrm{~mm}$ and 6.3 to $12.3 \mathrm{~mm}$, respectively. Another observation was that for the different plant parts, different concentrations showed significant differences in their activities against $E$. chrysanthema. However, the root, stem and flower extracts of A. conyzoides, and T. minuta, root and leaf extracts of $S$. incanum and root extracts of $O$. monacantha, did not show significant differences in the activities of different concentrations (Table 4).

We had varying results for phytochemical levels in the different plant parts for the different plants studied (Tables 5 and 6). Solanum incanum samples tested positive for all phytochemicals (steroids, anthraquinone, alkaloids, terpenoids, saponins, anthocyanin, flavonoids, phenols-tannins, and Ninhydrins). Levels of Ninhydrins were the highest in this plant with a mean of $17.04 \mathrm{mg} \mathrm{g}^{-1}$; followed by anthraquinones with a mean of $9.0 \mathrm{mg} \mathrm{g}^{-1}$, and trailing overall was phenol-tannins with a mean of $6.56 \mathrm{mg} \mathrm{g}^{-1}$ (Table 5).
The phytochemicals that recorded the least amounts in S. incanum were anthocyanins and saponins, with means of only 0.05 and 0.29 $\mathrm{mg} \mathrm{g}^{-1}$, respectively. There were no significant differences $(\mathrm{P}<0.05)$ in their quantities among the different plant parts for most of the phytochemicals, except for anthocyanins and anthraquinones where the levels were significantly different in different plant parts ( $\mathrm{P}=0.019$ and $\mathrm{P}=0.021$, respectively). The levels anthraquinones in the leaves of this plant were lower than in the other plant parts, with a mean of $9.03 \mathrm{mg} \mathrm{g}^{-1}$; while anthocyanins were more in the flowers and leaves $\left(0.05 \mathrm{mg} \mathrm{g}^{-1}\right)$; but lower in its roots and stems $\left(0.04 \mathrm{mg} \mathrm{g}^{-1}\right)$.

Although the flower, leaf, root and stem extracts of A. conyzoides contained all the phytochemical compounds tested, the levels of anthocyanins were particularly very low (average $0.035 \mathrm{mg} \mathrm{g}^{-1}$ ); while the levels of Ninhydrins were the highest, with an average of $17.33 \mathrm{mg} \mathrm{g}^{-1}$ (Table 5). The levels of steroids, alkaloids and terpenoids were almost similar across all the plant parts ranging from 2.54 to $2.56 \mathrm{mg} \mathrm{g}^{-1}$. Except for steroids, anthocyanins and flavonoids, the levels all the other phytochemicals were not significantly different across the different plant parts (P> 0.05) (Table 5). Similarly, for O. monacantha, the levels of steroids, alkaloids, anthocyanins, and ninhydrins all turned out to be significantly different across the stem, leaves, roots, and flowers $(\mathrm{P}<0.005)$ (Table 5). However, the levels of anthraquinones, terpenoids, saponins, flavonoids, and phenol-tannins were not significantly different across the different plant parts studied. Ninhydrins were recorded as the highest in this plant, with a mean of $16.51 \mathrm{mg}$ $\mathrm{g}^{-1}$; followed by anthraquinones with a mean of $9.96 \mathrm{mg} \mathrm{g}^{-1}$; and phenol-tannins with a mean of $6.325 \mathrm{mg} \mathrm{g}^{-1}$. The least levels of phytochemicals were recorded for anthocyanins with a mean of $0.052 \mathrm{mg} \mathrm{g}^{-1}$ and saponins mean of $0.265 \mathrm{mg} \mathrm{g}^{-1}$ (Table 5).

Results were observed for the levels of phytochemical compounds in E. tirucalli, with 
TABLE 4. Means of zones of inhibition ( $\mathrm{mm}$ ) of different concentrations of different plant extracts on Erwinia chrysanthema

\begin{tabular}{|c|c|c|c|c|c|c|c|c|}
\hline \multirow[t]{2}{*}{ Treatment } & \multirow[t]{2}{*}{---} & \multicolumn{3}{|c|}{ Ageratum conyzoides $----\cdots$} & \multicolumn{4}{|c|}{----- Opuntia monacantha ------} \\
\hline & & Bark & Leaf & Flower & Root & Bark & Leaf & Flower \\
\hline -VE control & $0.0 \pm 0.0 \mathrm{a}$ & $0.0 \pm 0.0 \mathrm{a}$ & $0.0 \pm 0.0 \mathrm{a}$ & $0.0 \pm 0.0 \mathrm{a}$ & $0.0 \pm 0.0 \mathrm{a}$ & $0.0 \pm 0.0 \mathrm{a}$ & $0.0 \pm 0.0 \mathrm{a}$ & $0.0 \pm 0.0 \mathrm{a}$ \\
\hline$+\mathrm{VE}$ control & $24.0 \pm 3.3 \mathrm{c}$ & $32.6 \pm 2.7 \mathrm{c}$ & $27.9 \pm 4.9 \mathrm{~d}$ & $33.3 \pm 2.3 \mathrm{c}$ & $30.9 \pm 3.0 \mathrm{c}$ & $28.7 \pm 3.9 \mathrm{e}$ & $30.8 \pm 4.3 \mathrm{~d}$ & $29.9 \pm 3.4 d$ \\
\hline Low conc. & $6.3 \pm 0.6 b$ & $7.7 \pm 1.5 b$ & $6.7 \pm 0.6 c$ & $6.0 \pm 1.0 \mathrm{~b}$ & $6.7 \pm 0.6 b$ & $6.7 \pm 1.1 b$ & $7.3 \pm 0.6 c$ & $9.0 \pm 1.0 \mathrm{~b}$ \\
\hline Med. conc. & $6.3 \pm 0.6 b$ & $7.0 \pm 1.0 \mathrm{~b}$ & $6.3 \pm 0.6 b$ & $6.3 \pm 0.5 b$ & $6.3 \pm 0.6 b$ & $9.3 \pm 0.7 \mathrm{c}$ & $6.3 \pm 0.5 b$ & $10.0 \pm 2.5 \mathrm{c}$ \\
\hline \multirow[t]{2}{*}{ High conc. } & $6.7 \pm 0.5 b$ & $8.7 \pm 1.2 b$ & $6.7 \pm 0.4 c$ & $6.7 \pm 0.6 b$ & $7.3 \pm 0.6 b$ & $11.0 \pm 0.5 \mathrm{~d}$ & $6.7 \pm 0.6 b c$ & $12.3 \pm .0 \mathrm{bc}$ \\
\hline & \multicolumn{4}{|c|}{$-----ー$ Tagetes minuta ------} & \multicolumn{4}{|c|}{------ Solanum incanum ------} \\
\hline -VE control & $0.0 \pm 0.0 \mathrm{a}$ & $0.0 \pm 0.0 \mathrm{a}$ & $0.0 \pm 0.0 \mathrm{a}$ & $0.0 \pm 0.0 \mathrm{a}$ & $0.0 \pm 0.0 \mathrm{a}$ & $0.0 \pm 0.0 \mathrm{a}$ & $0.0 \pm 0.0 \mathrm{a}$ & $0.0 \pm 0.0 \mathrm{a}$ \\
\hline$+\mathrm{VE}$ control & $16.6 \pm 1.8 \mathrm{c}$ & $16.1 \pm 1.6 \mathrm{c}$ & $17.7 \pm 2.5 \mathrm{~d}$ & $16.4 \pm 1.5 \mathrm{c}$ & $17.6 \pm 2.8$ & $15.7 \pm 1.5 \mathrm{~d}$ & $16.6 \pm 2.1 \mathrm{c}$ & $18.2 \pm 3.3 \mathrm{~d}$ \\
\hline Low conc. & $9.7 \pm 0.4 b$ & $9.3 \pm 0.6 b$ & $9.3 \pm 0.5 b$ & $9.0 \pm 0.6 \mathrm{~b}$ & $10.3 \pm 0.6 b$ & $9.7 \pm 0.6 b$ & $9.7 \pm 0.0 \mathrm{~b}$ & $9.7 \pm 0.6 b$ \\
\hline Med. conc. & $9.7 \pm 0.6 b$ & $10.3 \pm 3.2 b$ & $9.7 \pm 0.6 b c$ & $9.3 \pm 0.6 b$ & $10.7 \pm 0.5 b$ & $11.3 \pm 0.7 \mathrm{c}$ & $10.0 \pm 0.6 \mathrm{~b}$ & $10.0 \pm 0.0 \mathrm{bc}$ \\
\hline \multirow[t]{2}{*}{ High conc. } & $10.3 \pm 0.6 b$ & $11.3 \pm 0.6 \mathrm{~b}$ & $10.0 \pm 0.0 \mathrm{c}$ & $9.3 \pm 0.0 \mathrm{~b}$ & $12.0 \pm 2.6 \mathrm{~b}$ & $20.3 \pm 0.5 \mathrm{e}$ & $10.3 \pm 0.6 \mathrm{~b}$ & $10.3 \pm 1.2 \mathrm{c}$ \\
\hline & \multicolumn{4}{|c|}{ Euphorbia tirucalli ---} & \multicolumn{4}{|c|}{ 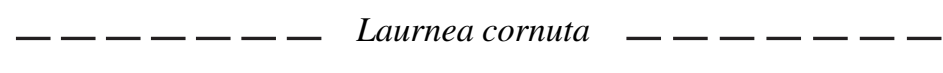 } \\
\hline -VE control & $0.0 \pm 0.0 \mathrm{a}$ & $0.0 \pm 0.0 \mathrm{a}$ & $0.0 \pm 0.0 \mathrm{a}$ & & $0.0 \pm 0.0 \mathrm{a}$ & $0.0 \pm 0.0 \mathrm{a}$ & $0.0 \pm 0.0 \mathrm{a}$ & $0.0 \pm 0.0 \mathrm{a}$ \\
\hline$+\mathrm{VE}$ control & $28.1 \pm 3.1 \mathrm{c}$ & $31.4 \pm 3.9 b$ & $30.8 \pm 4.6 \mathrm{c}$ & & $25.6 \pm 1.2 \mathrm{c}$ & $22.7 \pm 0.9 c$ & $28.7 \pm 2.9 \mathrm{~d}$ & $26.8 \pm 4.3 \mathrm{c}$ \\
\hline Low conc. & $15.7 \pm 0.8 b$ & $24.0 \pm 6.1 \mathrm{~b}$ & $16.0 \pm 3.6 \mathrm{~b}$ & & $13.7 \pm 7.0 \mathrm{~b}$ & $14.7 \pm 4.3 b$ & $15.0 \pm 5.6 \mathrm{~b}$ & $14.7 \pm 4.7 b$ \\
\hline Med. conc. & $24.0 \pm 3.5 \mathrm{c}$ & $24.3 \pm 5.2 \mathrm{~b}$ & $18.3 \pm 2.1 b$ & & $18.7 \pm 5.6 b$ & $24.0 \pm 3.0 \mathrm{c}$ & $18.7 \pm 5.2 b c$ & $21.0 \pm 3.6 \mathrm{c}$ \\
\hline High conc. & $26.7 \pm 2.0 \mathrm{c}$ & $31.0 \pm 1.9 \mathrm{~b}$ & $28.7 \pm 0.6 c$ & & $29.0 \pm 3.2 \mathrm{c}$ & $25.3 \pm 3.0 \mathrm{c}$ & $22.0 \pm 1.1 \mathrm{c}$ & $26.7 \pm 3.1 \mathrm{c}$ \\
\hline
\end{tabular}

Means followed by the same letter(s) within each column do not differ significantly at $\mathrm{P}<0.05$ (HSD) 
TABLE 5. Levels of phytochemical compounds $\left(\mathrm{mg} \mathrm{g}^{-1}\right)$ in Solanum incanum, Ageratum conyzoides and Opuntia monacantha

\begin{tabular}{|c|c|c|c|c|c|c|c|c|c|}
\hline \multirow[t]{2}{*}{ PL. PART } & \multicolumn{9}{|c|}{--------} \\
\hline & STE & ANT & ALKA & TER & SAPO & ANTHO & FLAV & PHENO & NINHY \\
\hline $\mathrm{F}$ & $2.56 \mathrm{a}$ & $9.03 \mathrm{a}$ & $2.78 \mathrm{a}$ & $2.53 \mathrm{a}$ & $0.29 a$ & $0.05 \mathrm{~b}$ & $1.53 \mathrm{a}$ & $6.52 \mathrm{a}$ & $17.13 \mathrm{a}$ \\
\hline $\mathrm{L}$ & $2.60 \mathrm{a}$ & $9.06 \mathrm{ab}$ & $2.77 \mathrm{a}$ & $2.53 \mathrm{a}$ & $0.28 \mathrm{a}$ & $0.05 b$ & $1.63 \mathrm{a}$ & $6.57 \mathrm{a}$ & $17.11 \mathrm{a}$ \\
\hline $\mathrm{R}$ & $2.52 \mathrm{a}$ & $9.07 \mathrm{~b}$ & $2.76 \mathrm{a}$ & $2.54 \mathrm{a}$ & $0.28 \mathrm{a}$ & $0.04 a$ & $1.50 \mathrm{a}$ & $6.55 \mathrm{a}$ & $17.13 \mathrm{a}$ \\
\hline $\mathrm{S}$ & $2.52 \mathrm{a}$ & $9.06 \mathrm{~b}$ & $2.78 \mathrm{a}$ & $2.54 \mathrm{a}$ & $0.29 \mathrm{a}$ & $0.04 \mathrm{a}$ & $1.49 \mathrm{a}$ & $6.61 \mathrm{a}$ & $17.04 \mathrm{a}$ \\
\hline Mean & 2.55 & 9.06 & 2.77 & 2.53 & 0.29 & 0.05 & 1.54 & 6.56 & 17.10 \\
\hline $\mathrm{CV}(\%)$ & 12.5 & 10.1 & 10.3 & 9.4 & 11.1 & 13.5 & 6.7 & 10.6 & 10.4 \\
\hline $\mathrm{P}$ value & 0.418 & $0.021^{*}$ & 0.090 & 0.419 & 0.361 & $0.019 *$ & 0.390 & 0.119 & 0.438 \\
\hline
\end{tabular}

\begin{tabular}{|c|c|c|c|c|c|c|c|c|c|}
\hline $\mathrm{F}$ & $2.58 \mathrm{~b}$ & $9.04 \mathrm{a}$ & $2.55 \mathrm{a}$ & $2.56 \mathrm{a}$ & $0.28 \mathrm{a}$ & $0.04 \mathrm{~b}$ & $1.66 \mathrm{~b}$ & $6.63 a$ & $17.32 \mathrm{a}$ \\
\hline $\mathrm{L}$ & $2.55 \mathrm{~b}$ & $9.05 \mathrm{a}$ & $2.56 \mathrm{a}$ & $2.55 \mathrm{a}$ & $0.28 \mathrm{a}$ & $0.03 \mathrm{ab}$ & $1.67 \mathrm{~b}$ & $6.63 a$ & $17.33 \mathrm{a}$ \\
\hline $\mathrm{R}$ & $2.54 \mathrm{a}$ & $9.06 \mathrm{a}$ & $2.57 \mathrm{a}$ & $2.55 \mathrm{a}$ & $0.28 \mathrm{a}$ & $0.03 \mathrm{a}$ & $1.49 \mathrm{a}$ & $6.65 \mathrm{a}$ & $17.34 \mathrm{a}$ \\
\hline 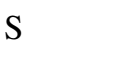 & $2.54 \mathrm{a}$ & $9.05 \mathrm{a}$ & $2.56 \mathrm{a}$ & $2.55 \mathrm{a}$ & $0.28 \mathrm{a}$ & $0.03 \mathrm{ab}$ & $1.60 \mathrm{~b}$ & $6.67 \mathrm{a}$ & $17.32 \mathrm{a}$ \\
\hline Mean & 2.551 & 9.049 & 2.561 & 2.552 & 0.276 & 0.035 & 1.60 & 6.645 & 17.33 \\
\hline $\mathrm{CV}(\%)$ & 10.5 & 9.2 & 11.3 & 20.1 & 17.0 & 12.8 & 12.2 & 16.4 & 19.1 \\
\hline P value & $0.027^{*}$ & 0.867 & 0.107 & 0.051 & 0.609 & $0.043 *$ & $0.002 *$ & 0.368 & 0.781 \\
\hline
\end{tabular}

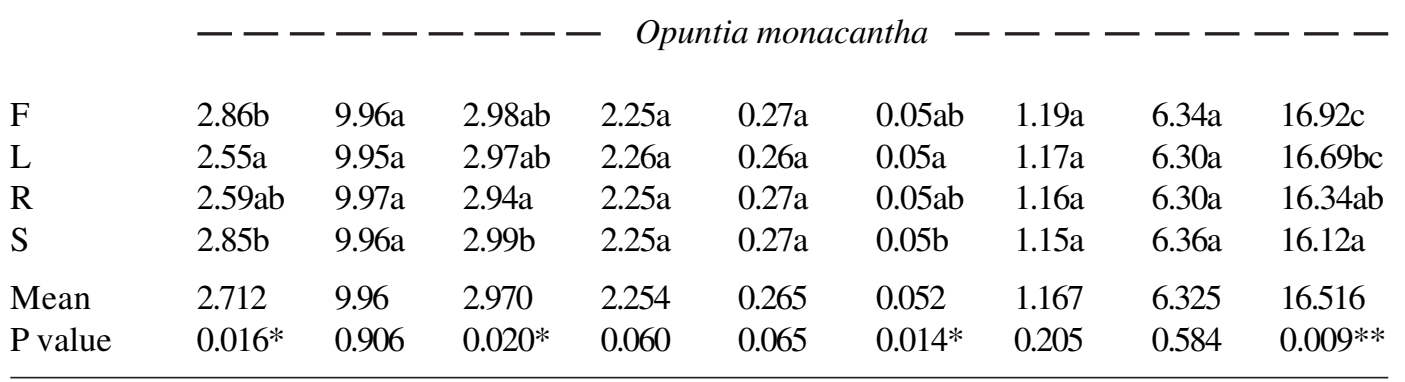

Means followed by the same letter(s) within each column do not differ significantly at $\mathrm{P}<0.05)$. $\mathrm{F}=$ Flower, $\mathrm{L}=$ Leaf, $\mathrm{R}=$ Root, $\mathrm{S}=$ Stem, $\mathrm{STE}=$ Steroids, $\mathrm{ANT}=$ Anthraquinone, ALKA = Alkaloids, TERP $=$ Terpenoids, $\mathrm{SAPO}=$ Saponins, $\mathrm{ANTHO}=$ Anthocyanin, FLAV $=$ Flavonoids, $\mathrm{PHENO}=$ Phenolstannins, NINHY = Ninhydrins

only levels of steroids and flavonoids being significantly different across the different plant parts $(\mathrm{P}<0.05)$ (Table 6$)$. The levels of the rest of the phytochemical compounds were not significantly different in the different plant parts. The levels of ninhydrins, anthraquinones and phenol-tannins were the highest in all the plant parts with means of $15.02,10.106$ and $5.966 \mathrm{mg} \mathrm{g}^{-1}$, respectively; while levels of anthocyanins and saponins were the least with means of 0.05633 and $0.2624 \mathrm{mg} \mathrm{g}^{-1}$ respectively. The levels of steroids and alkaloids were, however, almost similar in all parts of this plant.

The results recorded for $L$. cornuta phytochemical levels were very different from those recorded for all the other plants under study. Flavonoids and ninhydrins were 
TABLE 6. Levels of phytochemical compounds $\left(\mathrm{mg} \mathrm{g}^{-1}\right)$ in Euphorbia tirucalli, Laurnea cornuta and Tagetes minuta

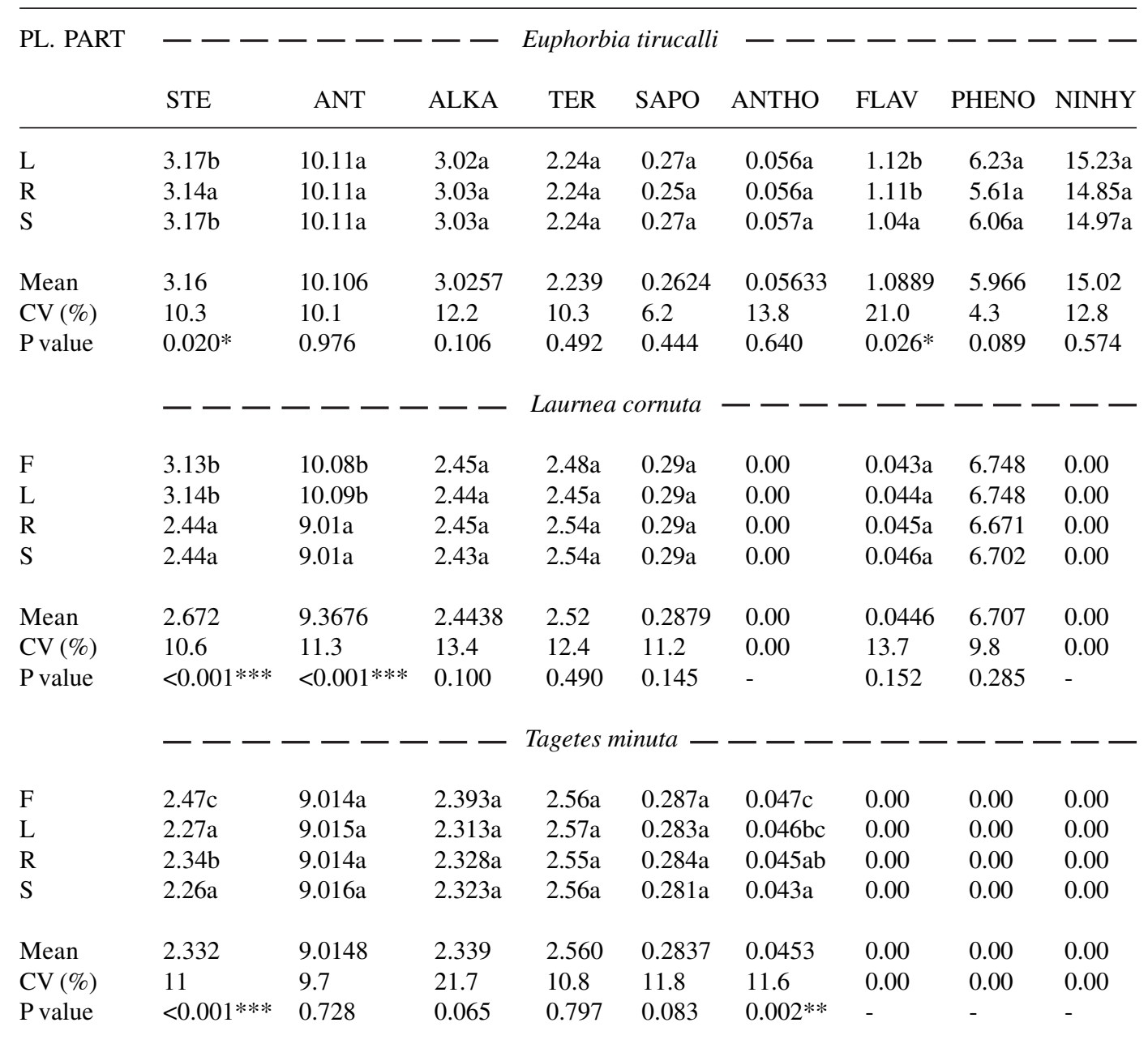

Means followed by the same letter(s) within each column do not differ significantly at $\mathrm{P}<0.05)$. $\mathrm{F}=$ Flower, $\mathrm{L}=$ Leaf, $\mathrm{R}=$ Root, $\mathrm{S}=$ Stem, $\mathrm{STE}=$ Steroids, $\mathrm{ANT}=$ Anthraquinone, ALKA = Alkaloids, TERP $=$ Terpenoids, $\mathrm{SAPO}=$ Saponins, $\mathrm{ANTHO}=$ Anthocyanin, FLAV $=$ Flavonoids, $\mathrm{PHENO}=$ Phenolstannins, NINHY = Ninhydrins

completely missing in extracts from all parts of $L$. cornuta (Table 6). For the rest of the phytochemicals, which were present in parts of this plant, significant differences were observed only for steroids and anthocyanins $(\mathrm{P}<0.05)$. The levels of anthraquinones and phenol-tannins were the highest with means of 9.3676 and $6.707 \mathrm{mg} \mathrm{g}^{-1}$, respectively; while levels of anthocyanins and saponins were the least with means of 0.0466 and $0.2879 \mathrm{mg}$ $\mathrm{g}^{-1}$, respectively (Table 6).
For T. minuta, flavonoids, phenol-tannins, and ninhydrins were completely lacking in all the plant parts, and only the levels of steroids and anthocyanins were significantly different across the different plant parts $(\mathrm{P}<0.05)$ (Table 6). Similarly, only the levels of anthraquinones were high in this plant, with a mean of $9.0148 \mathrm{mg} \mathrm{g}^{-1}$; whereas the levels of saponins and anthocyanins were very low with means of 0.28367 and $0.04533 \mathrm{mg} \mathrm{g}^{-1}$ respectively. However, the levels of steroids, 
alkaloids, and terpenoids were almost similar in this plant with means of 2.332, 2.339 and $2.560 \mathrm{mg} \mathrm{g}^{-1}$ respectively (Table 6).

\section{DISCUSSION}

The investigations revealed that most of the extracts had remarkable inhibitory activities on the growth of $F$. oxysporum. The high concentrations of $L$. cornuta extracts and the flower extracts of $S$. incanum yielded the best results in terms of in vitro inhibition of this pathogen and were significantly higher than the means recorded from the standard antibiotic used in the study.

The extracts of E. tirucalli were also promising in controlling the growth of this pathogen in vitro (Table 2). These results concur with those of a previous study where the extracts of $E$. tirucalli were reported to exhibit excellent antimicrobial activities against laboratory isolates of $F$. oxysporum (Bhuvaneshwar et al., 2010). The present findings also concur with those of other studies on antifungal activities of extracts from members of the Euphorbiaceae family, where root extracts recorded larger zones of inhibition zones than bark extracts (Rajeh et al., 2010; Karimi et al., 2011), but such variations attribute to the variations in phytochemical composition can be expected for different plant species (Vallejo et al., 2003; Randrianalijaona et al., 2005). Previous investigations involving extracts of E. tirucalli also indicate its antimicrobial activity against various fungal strains like Candida albicans (Bhalodia and Shukla, 2011; Singh and Vidyasagar, 2015). The bark extracts of E. tirucalli are also documented to be effective against F. oxysporum and other fungal pathogens (Rathi et al., 2012; de Araújo et al., 2014).

Although the antifungal activities of different $A$. conyzoides extracts against $F$. oxysporum were lower than the activities of most other plants, better antifungal activities by $A$. conyzoides acetone extracts have been reported (Pal and Kumar, 2013). The antimicrobial activities of the studied plant extracts were considerably lower against this fungal pathogen as compared to the bacterial pathogens. This can be attributed to the differences in cell wall composition between bacterial and fungal organisms, since fungal cell walls contain polysaccharides and proteins which are reported to function as efflux systems that expel deleterious compounds out of their cells (Nester et al., 2004).

The inhibitory activities of all the tested crude plant extracts against $F$. oxysporum increased with corresponding increase in their concentrations, showing that their effectiveness depends not only on their nature but also on the quantity of bio-active ingredients they contain. The increase in concentrations of the extracts, thus implies an increase in the quantity of the active antifungal ingredients, which in turn lowered the growth of $F$. oxysporum on the agar medium. These results show that higher concentrations of these plant extracts have the potential of significantly inhibiting mycelial growth and could be lethal to this pathogen, and therefore should be investigated for the management of Fusarium wilt of tomato.

This study has also established the antimicrobial effects of the root, bark, leaf and flower extracts of the different plant extracts tested against the tomato wilt-causing bacterium; S. solanacearum. The flower extracts of A. conyzoides had better effectiveness against this pathogen than it did on $F$. oxysporum and $E$. chrysanthema. It should be evaluated further for its potential in the management of the tomato bacterial wilt disease. However, the root, bark and leaf extracts of A. conyzoides, as well as the leaf, root and flower extracts of $O$. monacantha, exhibited relatively lower antimicrobial activities against this tomato wilt-causing pathogen, showing that they may not be the best extracts with regards to the management of tomato bacterial wilt disease. Contrastingly, in a previous study (Okwori et al., 2006), relatively higher antimicrobial activities were 
recorded for the stem, leaf and root extracts of $A$. conyzoides against different bacterial pathogens, but the tested organisms were clinical isolates and this can account for the observed differences.

Concentrations of the flower extracts of E. tirucalli exhibited the highest inhibitory effects against $S$. solanacearum, with means ranging from $13.3 \pm 7.3$ to $34.0 \pm 3.6 \mathrm{~mm}$. It was also noted that root extracts of $E$. tirucalli were more effective against this bacterial wilt than the root extracts of all other plants; and that even the low concentrations of these extracts yielded higher means of zones of inhibition than the high concentrations of all its other parts and of all other plant extracts.

Antibacterial activities of different Euphorbia species are documented (Annapurna et al., 2004; Sudhakar et al., 2006).

Although only aqueous E. tirucalli extracts were tested in the present study ethanolic $E$. tirucalli bark extracts are also documented to possess broad-spectrum antimicrobial activities against Gram-negative bacterial pathogens (de Araújo et al., 2014; Muthukumar et al., 2014), similar to the test pathogens in this study. These results indicate the high potential of the use of E. tirucalli plant extracts in the management of tomato bacterial wilt disease caused by this pathogen.

Extracts of roots, flowers, barks and leaves of T. minuta, L. cornuta and S. incanum had similar effects on $S$. solanacearum as portrayed in the recorded zones of inhibition, ranging from $8.7 \pm 0.6$ to $19.3 \pm 3.1 \mathrm{~mm}$. Solanum incanum is reported to be one of the most potent plants against microorganisms and its antimicrobial effects have been illustrated in previous studies (Britto and Senthikumar, 2001; Bari et al., 2010; Pavitra et al., 2012).

The extracts of $L$. cornuta exhibited even better inhibitory activities against $E$. chrysanthema than they did on $S$. solanacearum (Table 4). Both the medium and high concentrations of different extracts of this plant yielded means of zones of inhibition of up to $24.0 \pm 3.0$ and $29.0 \pm 3.2 \mathrm{~mm}$, respectively. Furthermore, no significant differences were observed in the antibacterial activities of the high and medium concentrations of the bark and flower extracts of this plant against E. chrysanthema. Generally, for this pathogen, E. tirucalli and L. cornuta extracts were more effective and yielded greater means zones of inhibition than all the other plant extracts.

Extracts of $T$. minuta and $S$. incanum exhibited moderate antibacterial activities against this pathogen, ranging from $9.0 \pm 0.6$ for the flower extracts of $T$. minuta to $20.3 \pm$ $0.5 \mathrm{~mm}$ for the bark extracts of $S$. incanum. The root, bark, and flower extracts of $O$. monacantha and A. conyzoides, the root extracts of $O$. monacantha and $S$. incanum, as well as the bark extracts of E. tirucalli showed no significant differences in their antibacterial activities against this pathogen between the low, medium and high concentrations. Generally, A. conyzoides and $O$. monacantha seemed to yield the least antimicrobial activities against this particular pathogen even at the high concentration.

The crude extracts of different plant parts in this study showed varying quantities of phytochemical compounds (Tables 5 and 6). A number of phytochemicals like alkaloids, saponins and flavonoids reported to be produced by several plants (Okwu, 2004; Jaberian et al., 2013), were present in all plant extracts exhibiting antibacterial and antifungal activities in this study. According to Muthu et al., (2006) and Krishnaraju et al. (2007), phytochemicals are responsible for the antimicrobial activities exhibited by different plant extracts. Reports also indicate that the antimicrobial activities of plant extracts can be linked to the abundance of phytocompounds in them (Wang, 2010; Phadungkit et al., 2012).

Phytochemical screening of extracts of different parts of $S$. incanum and $A$. conyzoides revealed the presence of all tested compounds in varying quantities (Table 5). 
Other studies have also confirmed the presence of alkaloids, saponins, flavonoids, tannins, and steroids in extracts of $S$. incanum (Amadi et al., 2010) and A. conyzoides (Amadi et al., 2002; Borkataky et al., 2013). In fact, these two plants portrayed the greatest quantities of flavonoids in their plant extracts, with means of 1.54 and $1.60 \mathrm{mg} \mathrm{g}^{-1}$, respectively.

Previous studies have also reported flavonoids to have inhibitory activities and to possess antifungal and antibacterial properties against several plant pathogens, including $F$. oxysporum (Cushnie and Lamb, 2005; Galeotti et al., 2008). More recently, some researchers have confirmed that the bioactive components of flavonoids contain antifungal and antibacterial activities (Abdel-Ghani et al., 2013), as was also determined in the present study, making these two plants to be highly important for control of bacterial wilt pathogens of tomato. These results suggest that $A$. conyzoides and $S$. incanum, by virtue of containing these compounds in greater quantities in their extracts, have the potential of effectively being used in the control of the wilt-causing pathogens evaluated in this study.

Except for steroids, anthocyanins, and flavonoids, the quantities of phytochemicals in extracts from different parts of $A$. conyzoides were not significantly different $(\mathrm{P}$ $>0.05$ ). In more recent studies, extracts of A. conyzoides also tested positive for alkaloids, saponins, flavonoids, phenols, tannins, and steroids (Odeleye et al., 2014). These results are also comparable to those obtained by other researchers, that demonstrated the presence of these phytocompounds in A. conyzoides (Amadi et al., 2002; Borkataky et al., 2013). More recently, it was also demonstrated that A. conyzoides extracts contained alkaloids, terpenoids, flavonoids, tannins, and saponins with means of $25.23,11.80,1.68,3.48$ and $20.73 \mathrm{mg} \mathrm{g}^{-1}$, respectively (Ajayi et al., 2016). Although these means are relatively higher than what was recorded in the present study, these differences can be attributed to geographical locational differences of the plants which have been shown to impact on the types and quantities of phytocompounds (Vallejo et al., 2003; Badoni et al., 2009; Gupta et al., 2011).

Results of phytochemical composition and quantities in extracts of different parts of $O$. monacantha revealed that this plant contained the highest means of alkaloids, exceeded only by of extracts of E. tirucalli (Table 5). Literature suggests that alkaloids are potent phytochemicals in plant extracts (Kaur et al., 2017). Studies carried out on alkaloids extracted from a variety of medicinal plants in Nigeria, showed great antifungal activities and antimicrobial activities against both Gramnegative and Gram-negative bacteria (Garba and Okeniyi, 2012). Alkaloids are reported to exhibit great antimicrobial activity against other bacterial pathogens such as Escherichia coli, Klebsiella pneumonia, Staphylococcus aureus and Pseudomonas aeruginosa (Maatalah et al., 2012), all of which are also bacterial pathogens of similar nature to those under the present study. These results imply that alkaloidcontaining extracts like those of $O$. monacantha can effectively be used in inhibiting the growth of these bacterial cells responsible for the wilt disease in tomato.

This present study also established the presence of all studied phytochemicals in extracts of E. tirucalli plant parts, corresponding to its excellent antimicrobial activities against the tested microorganisms with zones of inhibition exceeding $14.00 \mathrm{~mm}$. The results also indicated extracts of $E$. tirucalli had the highest levels of steroids, anthocyanins, and alkaloids of all the investigated plants (Table 6). Literature confirms that E. tirucalli extracts contain alkaloids, tannins, and phenols, all of which form the basis of its strong antimicrobial activities (Sugukumar et al., 2010). The presence of flavonoids and steroids as key phytoconstituents in E. tirucalli extracts is also reported by Ajayi et al. (2016), making its extracts to be highly potent to microbial cells. Flavonoids, for instance, effectively inhibit bacterial growth due to its ability to form 
complexes with the extracellular cell wall proteins, thereby disrupting microbial membranes (Hemandez et al., 2000).

Steroids are known for their antibacterial activity by causing leakages in microbial membrane proteins (Epand et al., 2007). Furthermore, the phenolic compounds of $E$. tirucalli are also documented to be toxic to microorganisms and similarly, the tannins produced by it can inhibit bacteria by inactivating microbial adhesion, enzyme functions and cell-envelope proteins (Upadhyay et al., 2010). Except for flavonoids and steroids, no significant differences were observed in the quantities of other phytochemicals in extracts of different parts of E. tirucalli. These results are slightly different from previous reports concerning other species from the Euphorbiaceae family where different plant parts contain different quantities of phytoconstituents (Igbinosa et al., 2009; Kamba and Hassan, 2010).

Extracts from all parts of $L$. cornuta did not portray the presence of anthocyanins and ninhydrins in the present study. Nevertheless, L. cornuta extracts still showed remarkable antimicrobial activities against the test pathogens, implying that anthocyanins may have no antimicrobial significance but could be important as antioxidant compounds as argued previously (Yin and Chao, 2008). Thus, the observed fungal and bacterial toxic effects exhibited by the crude plant extracts of $L$. cornuta against the test pathogens in this study may have been due to other phenolic constituents of this plant.

Similarly, extracts of all parts of $T$. minuta lacked flavonoids, phenol-tannins, and ninhydrins (Table 6). Our study findings are similar to those obtained in a study carried out in Pakistan, which confirmed the presence of phytochemicals flavonoids, saponins, tannins, and alkaloids, but not phenol-tannins in $T$. minuta extracts used against Gram-positive and Gram-negative bacteria (Tahir and Khan, 2012). The present study demonstrated that T. minuta extracts lacked flavonoids and phenol-tannins, contradicting other studies which have observed the presence of these compounds in T. minuta extracts used against both Gram-positive and Gram-negative bacteria (Tereschuk et al., 1997; Tahir and Khan, 2012). These variations can be due to differences in geographical locations of the plant since the two studies were done in Pakistan and Argentina, respectively. Evidence suggests that geographical differences impact on phytochemical quality and quantity in plant species, thereby affecting presumed antimicrobial properties (Howard et al., 2002; Vallejo et al., 2003; Yang et al., 2004; Badoni et al., 2009; Gupta et al., 2011). The possible cause of these differences concerning plant phytochemicals in different geographical regions has been strongly attributed to differences in types of soil minerals (Fonseca et al., 2006; Borokini and Ayodele, 2012), and as such, the same plant growing in different geographical locations can have different phytochemical contents.

The absence of some phytochemicals in plant extracts has in the past been linked to the type of solvent used in the extraction (Markom et al., 2007). In the present study, although aqueous extracts were used, this may not be the case since the phytochemicals absent in T. minuta and L. cornuta were extractable in water for the other plants under study. Despite lacking these important antimicrobial phytochemicals, the extracts of $L$. cornuta and $T$. minuta still had appreciable levels of terpenoids, saponins, phenol-tannins, and anthocyanins, which are equally potent phytochemicals. For instance, saponins are highly antifungal (Delmas et al., 2000; Wang, 2010), and antibacterial (Li et al., 2012; Deshpande et al., 2013) with their antimicrobial properties, mainly attributed mainly to lysis of microbial membranes (Asl and Hosseinzadeh, 2008). This probably explains why extracts from these two plant still exhibited inhibition of $F$. oxysporum, $R$. solanacearum and E. chrysanthema. 


\section{ACKNOWLEDGEMENT}

We thank the University of Eldoret for funding this research under the $1^{\text {st }}$ Annual University of Eldoret Research Grants in 2016, and for providing laboratory and greenhouse research facilities for this work.

\section{REFERENCES}

Abdel Ghani, S.B., Mugisha, P.J., Wilcox, J.C., Grado, E.A., Medu, E.O., Lamb, A.J. and Brown, R.C. 2013. Convenient one-pot synthesis of chromone derivatives and their antifungal and antibacterial evaluation. Journal of Scientific Communications 43(11):1549-1556.

Agrios, G.M. 2005. Plant Pathology. Elsevier Academic Press, Amsterdam. 502pp.

Ajayi, G.N., Awala, S.I., Okhogbue, A.G., Ogunkeye, A.G. and Olaleye, B.F. 2016. Antibacterial efficacy of Ageratum conyzoides on Salmonella species isolated from suspected typhoid fever patients in Akure Metropolis, Nigeria. Journal of Advances in Medical and Pharmaceutical Sciences 6(2):2-9.

Akkopru, A. and Demir, S. 2005. Biological Control of Fusarium Wilt in Tomato Caused by Fusarium oxysporum f. sp. lycopersici by AMF Glomus intraradices and Some Rhizobacteria. Journal of Phytopathology 153:544-550. http://dx.doi.org/10.1111/ j.1439-0434.2005.01018.x.

Amadi, B.A., Duru, M.K. and Atgomuo, E.N. 2002. Chemical profile of leaf, root and flower of Ageratum conyzoides. Asian Journal of Plant Science and Research 2(4):428-432.

Amadi, B.A., Salami, S.O. and Eze, C.S. 2010. Antifungal properties and phytochemical screening of extracts of African Basil (Ocimum gratissimum L.). Agriculture and Biology Journal of North America 1(2):163-166.

Annapurna, J., Chowdary, I., Lalitha, G., Ramakrishna, S. and Iyengar, D. 2004.
Phytochemical screening and in vitro bioactivity of Cnidoscolus aconitifolius (Euphorbiaceae). Pharmaceutical Biology 42:91-93.

de Araújo, K.M., de Lima, A., Silva Jdo, N., Rodrigues, L.L., Amorin, A.G., Quelemes, P.V., Dos Santos, R.C., Rocha, J.A., de Andrades, E.O., Leite, J.R., Mancini-Filho, J. and da Trindade, R.A. 2014. Identification of phenolic compounds and evaluation of antioxidant and antimicrobial properties of Euphorbia tirucalli L. Antioxidants (Basel) 3(1):159-175.

Asl, M.N. and Hosseinzadeh, H. 2008. Review of pharmacological effects of Glycyrrhiza $s p$. and its bioactive compounds. Journal of Phytotherapy Research 22(6):709-724.

AVRDC. 2015. Annual Report. Shanhua,Taiwan: The World Vegetable Center, http://203.64.245.61/fulltext_pdf/ AR/2015.pdf. Accessed 21 June 2019.

Awoyinka, O.A., Bolagun, I.O. and Ogunnowo, A.A. 2007. Phytochemical screening and in vitro bioactivity of Cnidoscolus aconitifolius (Euphorbiaceae). Journal of Medicinal Plants Research 1(3):63-65.

Ayandiji, A.O.R. and Adeniyi, O.D. 2017. Determinant Post Harvest Losses among Tomato Farmers in Imeko-Afon Local Government area of Ogun State, Nigeria. Global Journal of Science Frontier Research 1(5):23-27.

Badoni, R., Semwal, D.K. and Rawat, U. 2009. Altitudinal variation in the volatile constituents of Artemisia nilagirica. International Journal of Essential Oil Therapeutics 3:66-68.

Bari, M.A., Islam, W., Khan, A.R. and Abdul, M. 2010. Antibacterial and antifungal activity of Solanum torvum (Solanaceae). International Journal of Agriculture and Biology 12(3):386-390.

Bhalodia, N.R. and Shukla, V.J. 2011. Antibacterial and antifungal activities from leaf extracts of Cassia fistula 1.: An ethnomedicinal plant. Journal of Advanced 
Pharmaceutical Technology and Research 2:104-109.

Bhattacharjee, R. and Dey, U. 2014. An overview of fungal and bacterial biopesticides to control plant pathogens and diseases. African Journal of Microbiology Research 8(7):1749-1769.

Bhuvaneshwar, U., Singh, K.P. and Kumar, A. 2010. Ethno-medicinal, Phytochemical and Antimicrobial studies of Euphorbia tirucalli L. Journal of Phytology 2:65-77.

Birech, R., Benhard, F. and Joseph, M. 2006. Towards reducing synthetic pesticides imports in favour of locally available botanicals in Kenya. International agricultural research for development Conference Proceedings 8-12.

Borkataky, M., Kakoty, B.B. and Salkia, L.R. 2013. Antimicrobial activity and phytochemical screening of some common asteraceae family. International Journal of Pharmaceutical Sciences Review and Research 23(1):116-120.

Borokini, T.I. and Ayodele, A.E. 2012. Phytochemical screening of Tacca leontopetaloides (L.) Kuntze collected from four geographical locations in Nigeria. International Journal of Modern Biotechnology 2:97-102.

Britto, S.J. and Senthikumar, S. 2001. Antimicrobial activities of Solanum incanum leaf extract. Asian Journal of Microbiology, Biotechnology and Environmental Science 3(1-2):65-66.

Chethana, B.S., Ganeshan, G., Rao, A.S. and Bellishree, K. 2012. In-vitro evaluation of plant extracts, bioagents and fungicides against Alternaria porri (Ellis) Cif. causing purple blotch diseases of onions. Pest Management in Horticultural Ecosystems 18(2):194-198.

Choi, Y.W., Hyde, K.D. and Ho, W.H. 1999. Single spore isolation of fungi. Fungal Diversity 3:29-38.

Cushnie, T.T. and Lamb, A.J. 2005. Antimicrobial activity of flavonoids.
International Journal of Antimicrobial Agents 26(5):343-356.

Delmas, F., Di Giorgio, C., Elias, R., Gasquet, M., Azas, N., Mshvildadze, V., Dekanosidze, G., Kemertelidze, E. and Timon-David, P. 2000. Antileishmanial activity of three saponins isolated from ivy, alpha-hederin, beta-hederin and hederacolchiside A1, as compared to their action on mammalian cells cultured in vitro. Planta Medica 66: 343-644.

Deny, T.P. 2006. Plant pathogenic Ralstonia species. In Bacteria Ralstonia species, Dordrecht: Springer.

Deshpande, S., Kewatkar, S. and Paithankar, V. 2013. Antimicrobial activity of Saponins rich fraction of Cassia auriculata Linn against various microbial strains. International Current Pharmaceutical Journal 2(4):85-87.

Engindeniz, S. and Ozturk, G.C. 2013. An economic comparison of pesticide application for processing and table tomatoes, a case study for Turkey. Journal of Plant Protection Research 53(3):230237.

Epand, R.F. Savage, P.B. and Epand, R.M. 2007. Bacterial lipid composition and the antimicrobial efficacy of cationic steroid compounds (Ceragenins). Biochimica et Biophysica Acta: Biomembranes 10:25002509.

Fonseca, J.M., Rushing, J.W., Rajapaske, N.C., Thomas, R.L. and Riley, M.B. 2006. Potential implications of Medicinal Plant Production in Controlled Environments: The case of Feverfew (Tannacetum parthenium). HortScience 41(3):531-535.

Galeotti, F., Barile, E., Curir, P., Dolci, M. and Lanzotti, V. 2008. Flavonoids from carnation (Dianthus caryophyllus) and their antifungal activity. Journal of Phytochemistry Letters 1(1):44-48.

Garba, S. and Okeniyi, S.O. 2012. Antimicrobial activities of total alkaloids extracted from some Nigerian medicinal 
plants. Microbiology and Antimicrobial Agents 4(3):60-63.

Gupta, S., Bhaskar, G. and Andola, C.H. 2011. Altitudinal variation in essential oil content in leaves of Zanthoxylum alatum a high value aromatic tree from Uttarakhand. Research Journal of Medicinal Plants 5(3):348-351.

Hanaa, R.M.F., Abdou, Z.A., Salama, D.A., Ibrahim, A.R. and Sror, H.A.M. 2011. Effect of Neem and Willow Aqueous Extracts on Fusarium Wilt Disease in Tomato Seedlings: Induction of Antioxidant Defensive Enzymes. Annals of Agricultural Science 56:1-7, http://dx.doi.org/10.1016/ j.aoas.2011.05.007.

Handa, S.S., Khanuja, S.P.S., Longo, G. and Rakesh, D.D. 2008. Extraction Technologies for medicinal and aromatic plants. 2. Trietse: International Centre for Science and High Technology.

Hemandez, N.E., Tereschuk, M.L. and Abdala, L.R. 2000. Antimicrobial activity of flavonoids in medicinal plants from Tafí del Valle (Tucumán, Argentina). Journal of Ethnopharmacology 73(1-2):317-322.

Howard, L.R., Pandjaitan, N., Morelook, T. and Gil, M.I. 2002. Antioxidant capacity and phenolic content of spinach as affected by genetics and growing season. Journal of Agriculture and Food Chemistry 50:5891-5896.

Igbinosa, O.O., Igbinosa, E.O. and Aiyegoro, O.A. 2009. Antimicrobial activity and phytochemical screening of stem bark extracts from Jatropha curcas (Linn). African Journal of Pharmacy and Pharmacology 3(2):58-62.

Jaberian, H., Piri, K. and Nazari, J. 2013. Phytochemical composition and in vitro antimicrobial and antioxidant activities of some medicinal plants. Food Chemistry 136:237-244.

James, J.D., Atcha-Ahowe, C., Gordonou, I., Baimey, H., Goergen, H., Sikirou, R. and Toko, M. 2010. Integrated Pest Management in Vegetable Production.
International Institute of Tropical Agriculture (IITA),.

Janse, J.D. 2012. Review on brown rot (Ralstonia solanacearum Race 3, biovar 2, phylotype IIb. Epidemiology and control in the Netherlands since 1995: A success story of integrated pest management. Journal of Plant Pathology 94(2):257-272.

Joshi, B., Lekhak, S. and Sharma, A. 2009. Antibacterial property of different medicinal plants: Ocimum sanctum, Cinnamomum zeylanicum, Xanthoxylum armatum and Origanum majorana. Journal of Science, Engineering and Technology 5(1):143-150. Kamba, A.S. and Hassan, L.G. 2010. Phytochemical screening and antimicrobial activities of Euphorbia balsamifera leaves, stems and root against some pathogenic microorganisms. African Journal of Pharmacy and Pharmacology 4(9):645652.

Karimi, E., Jaafar, H.Z. and Ahmad, S. 2011. Phytochemical analysis and antimicrobial activities of methanolic extracts of leaf, stem and root from different varieties of Labisa pumila Benth. Molecules 16(6):4438-4450.

Kim, D.I., Park, J.D., Kim, S.G., Kuk, H. and Jang, M.G. 2005. Screening of some crude plant extracts for their acaricidal and insecticidal efficacies. Journal of AsiaPacific Entomology 8:93-100.

Krishnaraju, A.V., Rao, T.V., Sundararaju, D., Vanisree, M., Tsay, H.S. and Subbaraju, G.V. 2007. Assessment of bioactivity of Indian medicinal plants using brine shrimp (Artemia salina) lethality assay. International Journal for Applied Sciences Engineering 3(2):152-160.

Li, R., Wang, M.Y. and Li, X.B. 2012. Chemical constituents and biological activities of genus Hosta (Liliaceae). Journal of Medicinal Plants Research 6(14):27042713.

Lin, Y.M., Chou, I.C., Wang, J.F., Ho, F.I., Chu, Y.J., Huang, P.C., Lu, D.K., Shen, H.L., Elbaz, M., Huang, S.M. and Cheng, 
C.P. 2008. Transposon mutagenesis reveals differential pathogenesis of Ralstonia solanacearum on tomato and Arabidopsis. Molecular Plant-Microbe Interactions 21:1261-1270.

Maatalah, M.B., Bouzidi, N.K., Bellahouel, S., Merah, B., Fortas, Z., Soulimani, R. and Derdour, A. 2012. Antimicrobial activity of the alkaloids and saponin extracts of Anabasis articulate. Journal of Biotechnology and Pharmaceutical Research 3(3):54-57.

Markom, M., Hasan, M., Ramli, W., Daud, W., Singh, H. and Jahim, J.M. 2007. Extraction of hydrolysable tannins from Phyllanthus niruri Linn: Effects of solvents and extraction methods. Separation and Purification Technology 52:487-496.

McGovernn, R.J. 2015. Management of Tomato diseases caused by Fusarium oxysporum. Crop Protection 73:78-93.

Muthu, C.; Ayyanar, M.; Raja, N. and Ignacimuthu, S. 2006. Medicinal plants used by traditional healers in Kanchipuram district of Tamil Nadu, India. Journal of Ethnobiology and Ethnomedicine 2:43.

Muthukumar, R., Chidambaram, R. and Ramesh, V. 2014. Biosynthesis of silver nanoparticles from $E$. tirucalli and to check its antimicrobial activity. Research Journal of Pharmaceutical, Biological and Chemical Sciences 5(2):589-596.

Nashwa, S.M.A. and Abo-Elyousr, A.M.K. 2012. Evaluation of various plant extracts against the early blight disease of tomato plants under green house and field conditions. Plant Protection Science 48(2):74-79.

Nduagu, C.; Ekefen, E.J. and Nwankiti, A.O. 2008. Effect of some crude plant extracts on growth of Colletotrichum capsici (Syd.) Butler and Bisby causal agent of pepper anthracnose. Journal of Applied Biological Sciences 6:184-190.

Nester, E.W., Anderson, D.G., Roberts, C.E., Pearshall, N.N. and Nester, M.T. 2004. Microscopy and Cell Structure, Application of Immune Responses, Wound Infections. In: Microbiology: A Human Perspective. McGraw-Hill, New York. pp. 507-508.

Obafemi, C.A., Akinpelu, D.A., Taiwo, O.O. and Adeloye, A. 2006. Antimicrobial activity of solvent extracts of Terminalia catappa Linn leaves. Ife Journal of Science 8:2933.

Odeleye, O.P., Oluyege, J.O., Aregbesola, O.A. and Odeleye, P.O. 2014. Evaluation of preliminary phytochemical and antibacterial activity of Ageratum conyzoides (L) on some clinical bacterial isolates. The International Journal of Engineering Science 3(6): 1-5.

Okwori, A., Dina, C., Junaid, S., Okeke, I., Adetunji, J. and Olabode, A. 2006. Antibacterial Activities of Ageratum conyzoides extracts on selected bacterial pathogens. The internet Journal of Microbiology 14(1):1-8.

Okwu, D.E. 2004. Phytochemicals and vitamin content of indigenous spices of South Eastern Nigeria. Journal of Sustainable Agriculture Environment 6:30-37.

Pal, G.K. and Kumar, B. 2013. Antifungal activity of some common weed extracts against wilt causing fungi, Fusarium oxysporum. International journal of current discoveries and innovations 2(1):62-67.

Pavitra, P.S., Janani, V.S., Charumathi, K.H., Indumathy, R., Sirisha, P. and Rama, S.V. 2012. Antibacterial activity of plants used in Indian herbal medicine. International Journal of Green Pharmacy 4(1):22-28.

Phadungkit, M., Somdee, T. and Kangsadalampai, K. 2012. Phytochemical screening, antioxidant and antimutagenic activities of selected Thai edible plant extracts. Journal of Medicinal Plants Research 6(5):662-666.

Radhi, M.Z.A., Radh, A.M.B., Adam, S.H.M., Hamid, M.N., Tony, P.S.H. and Tan, G.H. 2016. Efficacy of Smart Fertilizer for Combating Bacterial Wilt Disease in Solanum lycopersicum. Direct Research 
Journal of Agriculture and Food Science 4(7):137-143.

Rai, M. and Carpinella, M. 2006. Naturally occurring bioactive compounds. Elsevier, Amsterdam. 524pp.

Rajeh, M.A.B., Zuraini, Z., Sasidharan, S., Latha, L.Y. and Amutha, S. 2010. Assessment of Euphorbia hirta L. leaf, flower, stem and root extracts for their antibacterial and antifungal activity and brine shrimp lethality. Molecules 15(9):6008-6018.

Randrianalijaona, J.A., Ramanoelina, P.A.R., Rasoarahona, J.R.E. and Gaydouet, E.M. 2005. Seasonal and chemotype influences on the chemical composition of Lantana camara L.: Essential oils from Madagascar. Analytica Clinica Acta 545:46-52.

Rathi, S.G., Patel, K. and Bhaskar, V.H. 2012. Isolation of Herbal plants: Antifungal and antibacterial activities. Journal of Pharmaceutical Science and Bioscientific Research 2(1):25-29.

Sang, G.K., On-Sook, H., Na-Young, R., HoCheol, K., Ku-Hee, R., Jung, S., KyoungYul, R., Sok-Young, L. and Hyung, J.B. 2016. Evaluation of Resistance to Ralstonia solanacearum in Tomato Genetic Resources at Seedling Stage. Plant Pathology Journal 32(1):58-64.

Singh, P.S. and Vidyasagar, G.M. 2015. Antifungal screening of 61 folkloric medicinal plant extracts against dermatophytic fungi Trichophyton rubrum. Journal of Applied Pharmaceutical Science 5(5):38-40.

Sravani, P.Y., Kiranmavee, S., Narasimha, M., Reddy, V.S., Asha, S. and Bharath, K.R. 2014. In-vitro Experimental Studies on Selected Natural Gums and Resins for Their Antimicrobial Activity. Research Journal of Pharmaceutical Biological and Chemical Sciences 5(1):154.

Sudhakar, M., Rao, C., Rao, P., Raju, D. and Venkateswarlu, Y. 2006. Antimicrobial activity of Caesalpinia pulcherrima,
Euphorbia hirta and Asystasia gangeticum. Fitoterapia 77:378-380.

Sugukumar, S., Karthikeyan, S. and Gothandam, K.M. 2010. Preliminary phytochemical and antibacterial investigations of Euphorbia tirucalli stem extracts. Pharmacology Online 3:937-943.

Tahir, L. and Khan, N. 2012. Antibacterial potential of crude leaf, fruit and flower extracts of Tagetes minuta L. Journal of Public Health and Biological Sciences 1:70-74.

Tenover, F. C. 2006. Mechanisms of antimicrobial resistance in bacteria. American Journal of Medicine 119(6):310.

Tereschuk, M.L., Riera, M.V., Castro, G.R. and Abdala, L.R. 1997. Antimicrobial activity of flavonoids from leaves of Tagetes minuta. Journal of Ethnopharmacology 56(3):227-232.

Tomoko, N., Takashi, A., Hiromu, T., Yuka, I., Hiroko, M., Munekazu, I., Totshiyuki, T., Tetsuro, I., Fujio, A., Iria, I., Tsutomu, N. and Kazuhito, W. 2002. Antibacterial activity of extracts prepared from tropical and subtropical plants on methicillinresistant Staphylococcus aureus. Journal of Health Sciences 48:273-276.

Upadhyay, B., Singh, P.K. and Kumar, A. 2010. Ethnomedicinal, phytochemical and antimicrobial studies of Euphorbia tirucalli L. Journal of Phytology 2(4):65-77.

Vallejo, F., Tomas, B.F.A., Gonzalez, B.G.A. and Gacia, V.C. 2003. Total and individual glucosinolate contents in inflorescences of eight broccoli cultivars grown under various climatic and fertilization conditions. Journal of Science, Food and Agronomy 83:307-313.

Wagnitz, J.J. 2014. Biopesticides use in IPM for low desert vegetable and fruit production. Ph.D Thesis. University of Nebraska, Lincoln, England. 91pp.

Wang, G.X. 2010. In vivo antihelmintic activity of five alkaloids from Macelya microcarpa 
against Dactylogyrus intermedius in Yin, M.C. and Chao, C.Y. 2008. AntiCarassius auratus. Veterinary Parasitology 171:305-313.

Yang, H., Ding, C., Duan, Y. and Liu, J. 2004. Variation of active constituents of an important Tibet folk medicine Swertia mussotii Franch. (Gentianaceae) between artificially cultivated and naturally distributed.

Journal

of Campylobacter, anti-aerobic, and antioxidative effects of roselle calyx extract and protocatechuic acid in ground beef. International Journal of Food Microbiology 127(1-2):73-77.

Yuliar, N., Yanetri, A.N. and Koti, T. 2015. Recent Trends in Control Methods for Ethnopharmacology 98:31-35. Bacterial Wilt Diseases Caused by Ralstonia solanacearum. Journal of Microbes and Environment 30(1):1-11. 